POLSKA AKADEMIA UMIEJĘTNOŚCI

TOM XIII

KULTURA SŁOWIAN. ROCZNIK KOMISJI KULTURY SŁOWIAN PAU

2017

DOI 10.4467/25439561KSR.17.017.7887

Dorota GIL

Instytut Slawistyki PAN

Warszawa

\title{
KULTUROWE, RELIGIJNE I GEOPOLITYCZNE WYZNACZNIKI (AUTO)IDENTYFIKACJI CZARNOGÓRCÓW ${ }^{1}$
}

\author{
CULTURAL, RELIGIOUS AND GEOPOLITICAL MARKERS \\ OF THE (SELF)IDENTIFICATION OF THE MONTENEGRINS
}

\begin{abstract}
Streszczenie
W artykule omawiane są najważniejsze aspekty złożonej - utrudnionej względami geopolitycznymi - narodowej i kulturowej (auto)identyfikacji Czarnogórców, wpisanej w proces reinterpretacji ich rodzimej historii i tradycji narodowej. Jednym z kluczowych problemów Czarnogórców, funkcjonujących przez stulecia w obrębie wspólnej serbsko-czarnogórskiej kulturosfery, jest nie tylko ich tzw. podwójna tożsamość na poziomie jednostkowym, ale także wynikająca z istotnego zróżnicowania etniczno-kulturowego poszczególnych regionów Czarnogóry identyfikacja na poziomie ogólnonarodowym (trzy etnogeograficzne jednostki identyfikacji podstawowej, alternatywnej i hybrydycznej). W artykule wskazuje się na nadmierne upolitycznienie dyskursu tożsamościowego, które utrudnia próby konstruowania czarnogórskiego kanonu tradycji kulturowej oraz decyduje o wykorzystywaniu prawosławia (i lokalnych Cerkwi prawosławnych) oraz islamu jako narzędzi w służbie doraźnej polityki.
\end{abstract}

\section{Summary}

In the article the most important aspects of a complex - and impeded by geopolitical reasons - national and cultural (self)identification of the Montenegrins, which is inscribed into a process of the reinterpretation of their native history and tradition, are taken into con-

${ }^{1}$ Artykuł powstał w ramach projektu badawczego pt. „Idee wędrowne na słowiańskich Bałkanach (XVIII-XX w.)" finansowanego ze środków Narodowego Centrum Nauki; nr projektu 2014/13/B/ HS2/01057. 
sideration. One of the most crucial problems of the Montenegrins, who have been for centuries existing within a common Serbian-Montenegrin cultural sphere, is not just their double identity at an individual level but also the identification at a collective level that derives from an important ethnic-cultural complexity of certain Montenegrin regions (within three ethnogeographic entities: the basic, the alternative and the hybrid). In the article an overwhelming political instrumentalization of identity discourse is analyzed. It is responsible for impeding attempts of the constructions of the Montenegrin canon of the cultural tradition and makes it possible to utilize the Orthodoxy (including the local Orthodox Churches) and Islam as a tool in making current policy.

Słowa klucze: Czarnogórcy, (auto)identyfikacja, tradycja kulturowa, dyskurs tożsamościowy, Cerkiew czarnogórska

Key words: Montenegrins, (self)identification, cultural tradition, identity discourse, Montenegrin Orthodox Church

Czarnogóra - jedno z najmłodszych państw Europy, przez stulecia formalnie bądź ściśle geopolitycznie oraz ideologicznie zależne od Serbii i funkcjonujące w obrębie wspólnej serbsko-czarnogórskiej kulturosfery, jako ostatnia spośród byłych republik Jugosławii po jej rozpadzie w latach dziewięćdziesiątych XX wieku rozpoczęła proces reinterpretacji i kodyfikacji własnej „na chwilę zagubionej” tradycji kulturowej. Rzecz jasna rok 2006 (gdy państwo w wyniku referendum formalnie uzyskało niepodległość) z perspektywy zmian zachodzących w obrębie kultury należy traktować jako jedną z wielu, choć niewątpliwie najważniejszą datę symboliczną i historyczną cezurę. Międzynarodowe potwierdzenie istnienia odrębnej Czarnogóry zyskiwało bowiem w oczach większości jej mieszkańców wymiar „zwycięstwa prawdy historycznej” i umożliwiało przy słabym dotychczas instynkcie państwotwórczym zmianę perspektywy i sposobu postrzegania otoczenia - zarówno na płaszczyźnie politycznej, społecznej, jak i kulturowej, w centrum dyskursu stawiając problematykę tożsamościową w wymiarze etnicznym, narodowym, kulturowym czy religijnym. Rozpoczęty właśnie w latach dziewięćdziesiątych i zyskujący dynamikę od 2006 roku proces (re)konstruowania tożsamości czarnogórskiej oparty zatem zostanie na opozycyjnych układach odniesień do geopolitycznego otoczenia kraju oraz kreowaniu wyobrażonej wspólnoty kulturowej całego zintegrowanego narodu. Rosnące po 2000 roku niezadowolenie z realiów (już tylko prowizorycznej) politycznej federacji Serbii i Czarnogóry doprowadziło do wyartykułowania haseł separatystycznych i działań zmierzających do uzyskania niezależności od dawnego centrum. Jednym z kluczowych problemów podjętej przez miejscowych intelektualistów rekonstrukcji dziejów państwa czarnogórskiego oraz kodyfikacji tradycji kulturowej okaże się w tej sytuacji nie tylko mające swe źródła w - politycznie i kulturowo ujednoliconej przez stulecia - serbsko-czarnogórskiej kulturosferze zjawisko tak zwanej podwójnej tożsamości (zarówno na poziomie na- 
rodowym, jak i jednostkowym), ale także niezunifikowane, niejednorodne etnicznie i kulturowo wymiary przestrzeni własnego państwa. Funkcjonowało ono bowiem nie tylko w obrębie serbskiej formacji politycznej, ale także - w odniesieniu do poszczególnych regionów - poddawane było w ciągu stuleci oddziaływaniu odmiennych niż serbski (postbizantyjski, prawosławny) modeli kulturowych.

Przyczyn tego zjawiska podwójnej serbsko-czarnogórskiej tożsamości, wyróżniającego Czarnogórę spośród byłych republik jugosłowiańskich, które po rozpadzie wspólnego państwa musiały zmierzyć się z konsekwencjami unitarystycznej polityki Belgradu prowadzonej w okresie socjalistycznej Jugosławii, szukać należy jeszcze w wieku XIX. Chodzi tu zarówno o integracyjne (iliryzm i jugoslawizm), jak i dezintegracyjne (narodowe/nacjonalistyczne) koncepty ideologiczne, kształtujące wyobrażone (jak iluzoryczna Iliria, znosząca granice państw narodowych w obrębie południowosłowiańskiego etnicum) i bardziej realne (konstruowana między innymi według kryterium językowego Wielka Serbia) projekty, zamazujące kategorie przynależności etnicznej wspólnoty. Jeden ze znanych współczesnych myślicieli czarnogórskich Marko Špadijer, ów dziewiętnastowieczny, ale także nieco późniejszy brak własnej strategii narodowej Czarnogórców oraz stopniowy proces stawania się ich ojczyzny satelitą Serbii komentuje następująco:

„Pojmowanie tożsamości czarnogórskiej jako gałęzi wyrastającej z pnia serbskiego było kształtowane już w pierwszych [dziewiętnastowiecznych - D.G.] - tzw. Niegoszowskich szkołach podstawowych [...]. W zorganizowany sposób realizowano założenia Načertanija, serbskiego narodowego, wielkopaństwowego projektu z 1844 roku. Wojowniczemu etosowi Czarnogórców odpowiadało podsycanie przekonania, że są serbskimi Spartanami i giną w obronie prawosławnej kultury przed zakusami Imperium Osmańskiego. Czarnogórski król Nikola I rościł sobie nawet pretensje do serbskiego tronu. Zgodnie z tym planem [a z perspektywy serbskiej - raczej by temu zapobiec - D.G.] w 1918 roku brutalnie zniszczono czarnogórską tożsamość państwową i narodową, zlikwidowano czarnogórską Cerkiew, a historia i kultura zostały włączone do serbskiego uniwersum. Parlament Czarnogóry podczas okupacji serbskiej lakonicznie określił los swoich rodaków: «Od dziś w Czarnogórze nie ma Czarnogórców, są tylko Serbowie»"².

Jak wiadomo, w Titowskiej już Jugosławii podporządkowane zasadzie ,braterstwa i jedności” procesy unifikacyjne i asymilacyjne w ramach wspólnoty narodowej Jugosłowian skutkowały całkowitym niemal stapianiem się kultury Serbów i Czarnogórców i postrzeganiem jej jako jednej i jednorodnej. Sprzyjała temu wzmożona emigracja Czarnogórców do Serbii (głównie do Belgradu) w poszukiwaniu lepszych warunków do życia i ich szybki (już w drugim pokoleniu) proces stawania się Ser-

${ }^{2}$ M. Špadijer, Czarnogóra przed i po referendum [w:] Bunt tradycji - tradycja buntu, Księga dedykowana Profesorowi Krzysztofowi Wrocławskiemu, red. M. Bogusławska, G. Szwat-Gyłybowa, Warszawa 2008, s. 197. 
bami czarnogórskiego pochodzenia oraz konsekwentna polityka narodowościowa prowadząca do eliminacji w sferze życia publicznego w Czarnogórze wszelkich przejawów opozycji wobec opcji proserbskiej i do ukazywania czarnogórskiego dziedzictwa kulturowego jako osiągnięć serbskiej kultury i cywilizacji ${ }^{3}$. $Z$ tej perspektywy kultura czarnogórska mogła być uważana co najwyżej za swego rodzaju „regionalną odmianę” w obrębie dominującej kulturosfery i przedstawiana wyłącznie w jej kontekście. Na programowe zdefiniowanie innego punktu widzenia brakowało dostatecznie rozwiniętej elity, mogącej bronić na płaszczyźnie naukowej i politycznej podstawy narodowego interesu.

Także w XIX wieku - już w odniesieniu do drugiego z wcześniej sygnalizowanych problemów - poszukiwać należałoby współczesnych kłopotów Czarnogórców tym razem z ich (auto)identyfikacją etniczno-kulturową na poziomie ogólnonarodowym. Znaczący przyrost terytorialny kraju w drugiej połowie XIX stulecia skutkował połączeniem regionów etnicznie, historycznie i kulturowo odmiennych ${ }^{4}$, w kolejnym wieku nie do końca poddających się integracyjnym i unifikacyjnym procesom zmierzającym do zatarcia różnic - także etnopsychologicznych - pomiędzy reprezentantami poszczególnych kultur. Dziś w dalszym ciągu trudno byłoby uznać niejednorodne etnicznie, religijnie i kulturowo terytorium obecnej Czarnogóry za zogniskowane wokół jednego, uniwersalnego dla całej społeczności systemu wartości narodowych. $\mathrm{W}$ istocie na $\mathrm{z}$ trudem konstruowany w ostatnim dziesięcioleciu kanon tradycji kulturowej należałoby spojrzeć jako na system kilku modeli przestrzennych, pokrywających się z terytoriami poszczególnych regionów geograficznych, których rozwój przebiegał niezależnie od pozostałych, w różnym tempie oraz pod wpływem odmiennych czynników zewnętrznych.

Punktem wyjścia dla tworzenia ogólnonarodowego modelu identyfikacyjnego stał się wyrastający z ludowej zwłaszcza kultury tradycyjny system wartości, oparty na etnicznej „,czarnogórskości”, a odpowiadający przede wszystkim centralnej części kraju - czyli tak zwanej Czarnogórze właściwej z najważniejszymi ośrodkami kulturalnymi i administracyjnymi, jak Podgorica, Cetinje i Nikšić. Identyfikację - którą tu nazwijmy podstawowa ${ }^{5}$ - określa model kulturowy z dominującym wyznaniem

${ }^{3}$ Marko Špadijer wymienia m.in. Czarnogórską Akademię Nauk, która miała być przekształcona w filię Serbskiej Akademii Nauk i Umiejętności. Historyczna Drukarnia Crnojevicia promowana była jako serbska, Serbska Cerkiew Prawosławna wznosiła kolejne świątynie, a najwyższe nagrody literackie przyznawane były serbskim nacjonalistom - Dobricy Ćosiciowi, Matiji Bećkoviciowi czy Radovanovi Karadžiciowi. Por. ibidem.

${ }^{4} \mathrm{~K}$. Wrocławski, Mniejszość we własnym kraju? - rzecz o Czarnogórcach [w:] Literatury stowiańskie po roku 1989. Nowe zjawiska, tendencje, perspektywy, t. IV: Mniejszości, red. M. Dąbrowski, Warszawa 2005, s. 158-168.

${ }^{5}$ Przywołuję tu terminologię wypracowaną wspólnie z Katarzyną Sudnik w napisanej pod moim kierunkiem rozprawie doktorskiej Regionalne modele (auto)identyfikacji a integracja kulturowa i narodowa we wspótczesnej literaturze czarnogórskiej (Uniwersytet Jagielloński, 2016). 
prawosławnym i podstawowy zbiór symboli, postaci oraz wydarzeń kluczowych z punktu widzenia tożsamości narodowej, a więc historią państwowości (Duklja, Zeta, wreszcie Czarnogóra), czarnogórscy (tj. związani z obszarem kraju) święci (między innymi Jovan Vladimir z X w., traktowany przez autorów serbskich jako ich narodowy monarcha; Vasilije Ostroški - szanowany też przez muzułmanów i katolików; opisywani dotychczas często w odrębnych kontekstach narodowych Stefan Piperski, Joannikije Devički, Stefan Štiljanović czy Angelina Branković) i władcy (zwłaszcza władyka Petar II Petrović Njegoš oraz król Nikola I). Oblicze kształtujących się w ciągu stuleci paralelnie do omawianego dwóch innych modeli regionalnych w znaczącym stopniu określiły czynniki geopolityczne i religijne. Pierwszy z nich - nazwijmy go tutaj modelem identyfikacji hybrydycznej - reprezentuje zjawiska oparte na zachodnich - łacińskich i włoskich, czy też dalmatyńsko-dubrownickich źródłach kultury (dominującym w regionie do dziś) oraz wyznaniu rzymskokatolickim, obejmując tereny wybrzeża adriatyckiego (przede wszystkim Bokę Kotorską). Wiąże się jednak także ze stanowiącymi amalgamat etniczno-kulturowy południowo-wschodnimi kresami państwa (region Ulcinja), z przeważającym w nim pierwiastkiem albańskim i muzułmańskim (obok najliczniejszej tu grupy wyznawców islamu żyją także katolicy). Z kolei dla modelu kultury alternatywnego wobec prawosławnego i zorientowanego na „czarnogórskość” centrum oraz w większości katolickiej i mającej łacińskie korzenie kultury wybrzeża adriatyckiego - a ukształtowanego na wschodzie Czarnogóry, na obszarze tzw. Sandžaku (dziś podzielonego granicą Czarnogóry i Serbii) - dominantę i kod (auto)identyfikacji kulturowej Boszniaków, zamieszkujących ten obszar i utożsamiających się z muzułmanami z Bośni, stanowi islam. Oczywiście w dyskursie tożsamościowym stanowiącym podstawę konstruowanego przez elity intelektualne kanonu tradycji kulturowej te dwa ostatnie modele stanowią pierwiastek drugoplanowy - czyli elementy nie odpowiadające wzorcowi czystej „,czarnogórskości”, i są ukazywane jako charakterystyczne dla mniejszości narodowych, etnicznych i wyznaniowych - a zatem jednak „mało znaczące” dla pożądanego modelu kultury (ogólno)narodowej. Nadmierne upolitycznienie dyskursu tożsamościowego pozwala przy tym nawet obiektywne i rzetelne prace specjalistów w zakresie historii czy etnografii postrzegać w jego pryzmacie jedynie jako pewne strategie ideologiczne albo czysto propagandowe, odzwierciedlające różnorakie manipulacje faktami, czemu sprzyja brak kompleksowych syntez badawczych. Podobnie sytuacja wygląda z budową kanonu literatury narodowej, odzwierciedlającego powyższe trzy regionalne jednostki etnogeograficzne, wkomponowane teraz konsekwentnie w jeden etnopolityczny „organizm tekstów”. Od początku prowadziło to nierzadko do skrajnych, wręcz kuriozalnych sytuacji - braków w podstawowych opracowaniach, zmian programów nauczania, nadprodukcji studiów paranaukowych czy problemów terminologicznych. Ponadto podejmowane są od dłuższego czasu kroki w zakresie deserbizacji całej lokalnej to- 
ponomastyki - i naturalnie potwierdzone już ustawowo skuteczne próby kodyfikacji języka literackiego ${ }^{6}$.

Bez wątpienia jednym z najważniejszych problemów, z jakimi zmierzyć muszą się dzisiaj czarnogórscy konstruktorzy tego dyskursu (także w odrębnym wymiarze duchowni) jest miejsce i rola w obrębie całokształtu kultury dominującego w skali ogólnopaństwowej prawosławia. Nie stanowi bowiem ono - w przeciwieństwie do sytuacji w Serbii, ale także islamu obecnego w czarnogórskiej części Sandžaku - absolutnie podstawowego kodu autoidentyfikacji narodowej, ani też - jak powiedzieliby socjologowie religii - „twórczego kodu sensów” jednolitej tradycji kulturowej Czarnogórców. W Serbii znacznie dalej bowiem posunięty został proces sakralizacji etniczności pod szyldem „odnowy religijnej”, włączającej również pierwiastki mistyczne czy w dużej mierze pogańską ludową obrzędowość i obyczajowość. Wyjątek, choć tylko do pewnego stopnia, stanowią zorientowani „proserbsko” Czarnogórcy z tzw. podwójną (czarnogórsko-serbską) tożsamością ${ }^{7}$, czy też po prostu ci uważający się za Serbów. Mamy zatem z jednej strony przekonujące przykłady afirmacji prawosławia w wymiarze etnicznym czy narodowym, ale także przykłady de-etnizacji prawosławia z jednej, a z drugiej „montenegryzacji” tradycji łacińsko-katolickiej (widoczne na przykład zarówno w odniesieniu do prawosławnych, jak i katolickich kultów świętych wywodzących się z tutejszych terenów). Coraz liczniejsze stają się także w ostatnich latach w niektórych kręgach inteligencji naukowej i artystycznej próby całkowitej negacji zetnizowanego/unarodowionego (czytaj: upolitycznionego oraz zemblematyzowanego) prawosławia jako wiarygodnego kodu tożsamościowego ${ }^{8}$.

Przypomnijmy, że proces „rewitalizacji“ religii na obszarze Czarnogóry - wcześniej najbardziej zateizowanej republice w byłej Jugosławii (jeszcze w 1985 roku jako ateiści określało się blisko 80\% Czarnogórców, w roku 1991 ponad 62\%, ale już w 1993 ,religijni' sięgnęli niemal 70\% $)^{9}$ - przebiegał dużo wolniej niż na przykład w Serbii i choć dane statystyczne z przeprowadzonego w 2010 roku spisu powszechnego mówią o niebywałym wręcz wzroście liczby deklarujących się jako ,religijni'

${ }^{6}$ Na temat kodyfikacji języka czarnogórskiego zob. R. Bońkowski, Stowianie środkowopołudniowi na przełomie XX i XXI wieku. Język - Religia - Naród - Państwo, Katowice 2010, s. 83-92.

7 Por. Z. Lutovac, Srpski identitet u Crnoj Gori, Beograd 2015 oraz Ž. Andrijašević, Srpstvo u Crnoj Gori [w:] DOCLEA. Posebno izdanje - serija L: Falsifikati crnogorske prošlosti. Zbornik radova DANU, organizacioni odbor B. Nikolić et al., Podgorica 2011, s. 91-108.

8 Jednym z najbardziej wyrazistych przykładów negacji upolitycznionego i zemblematyzowanego (sprowadzanego często do religii Njegoša) prawosławia stała się opinia znanego współczesnego pisarza nurtu tzw. czarnogórskiej nowej prozy oraz publicysty Andreja Nikolaidisa, wyrażona w głośnej powieści Mimesis (zwłaszcza w rozdziale Loosing my religion) z 2003 roku.

${ }^{9}$ Por. S. Vukadinović, Uticaj djelovanja vjerskih zajednica na stanje religijske svijesti pripadnika društvenih grupa u Crnoj Gori [w:] Učenje, organizacija i delovanje verskih zajednica i pokreta (V godišnja medjunarodna konferencija JUNIR), ured. D. B. Djordjević, JUNIR V, Niš 2001, s. 82-84. 
(niemal 96\%, w tym prawosławnych $72 \%)^{10}$, to oczywiście nie oznacza, że współczesna Czarnogóra stała się krajem poddanym skutecznej rechrystianizacji i że religia (oprócz islamu dla Boszniaków) stanowi już zdecydowanie istotny i powszechnie uświadamiany kod czarnogórskiej (auto)identyfikacji i tradycji kulturowej.

Należy przy tym pamiętać, że dane statystyczne nie odzwierciedlają faktycznego stanu świadomości religijnej. Jej dzisiejszy ksztalt, zważywszy na wciąż - jak mówi

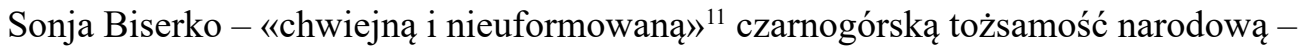
określa szereg różnorodnych czynników: nadal niestabilna płaszczyzna podziału pomiędzy tożsamością etniczną/narodową a religijną, w dużej mierze związana z konkretnym Kościołem instytucjonalnym w obrębie jednego wyznania; świadomość wspomnianej już wcześniej tzw. podwójnej tożsamości narodowej (serbsko-czarnogórskiej), ale także podwójnej/potrójnej tożsamości kulturowej regionu pogranicza cywilizacyjnego, jakim jest Czarnogóra. Wydaje się, że współczesny dyskurs o prawosławiu jako istotnym elemencie czarnogórskiej tożsamości sprowadza się do trzech podstawowych płaszczyzn. Po pierwsze, chodzi o afirmację prawosławia w wymiarze etnicznym, za animatorów której uznać można w pierwszym rzędzie duchownych, ale także intelektualistów akcentujących swój związek z prawosławiem. Dyskurs ten ma swoje cechy specyficzne, uwarunkowane sytuacją geopolityczną i historyczną kształtowaną w ciągu wieków w relacjach Czarnogórców i Serbów, jednak wbrew pozorom nie stanowi on ewenementu w skali krajów postsocjalistycznych - przypomnijmy tu choćby dwie najczęściej przywoływane analogie: prawosławia macedońskiego i ukraińskiego. W odniesieniu bowiem do sfery instytucjonalnej w swych dążeniach do usamodzielnienia się tzw. Czarnogórska Cerkiew Prawosławna („bardziej zracjonalizowana od serbskiej z powodu bliskości Rzymu"12, dalej CCP) identyfikuje się w dużej mierze z podobnym statusem niekanonicznej Macedońskiej Cerkwi Prawosławnej; znamienne też, że jeszcze dobitniej podkreśla swe związki z niekanoniczną Ukraińską Cerkwią Patriarchatu Kijowskiego, w obrębie której dostrzega najbardziej zbliżony do własnego, defensywny wobec silniejszych „siostrzanych” instytucji reli-

${ }_{10}$ Pod. za: Rezultati popisa u Crnoj Gori, http://popis2011.wordpress.com/2011/07/12/zvanicni-rezultati-popisa-crnogoraca, dostęp: 15.06.2012. Według ankiety Macierzy Czarnogórskiej za wierzących i praktykujących uważa się $68 \%$ obywateli, umiarkowanie religijnych $-9 \%$, ateistów $-6,7 \%$, niezdecydowanych - 16,1\%. Ta sama ankieta podaje stosunkowo wysoki (ok. 1/3) odsetek respondentów nie mających określonego stanowiska w sprawie sporu między dwiema czarnogórskimi Cerkwiami. Por. Stavovi crnogorskih gradjana o idetitetu. Istraživanje CEDEM-a sa komentarom, http://www.maticacrnogorska.me/files/54/04\%20crnogorski\%20gradjani\%20o\%20identitetu.pdf, dostęp: 18.06. 2012.

${ }^{11}$ Por. N. Zečević, Beograd je frustriran rezultatima popisa - razgovor sa predsjednicom Helsinškog komiteta Sonjom Biserko (19.07.2011), http://www.portalanalitika.me/politika/tema/32150beograd-je-frustriran-rezultatima-popisa.html, dostęp: 28.09.2011.

12 Por. A. Avdić, Osobitosti crkve u Crnoj Gori, rad iz predmeta Antropologija etniciteta, Odeljenje za Etnologiju i antropologiju, Filozofski fakultet, Beograd, 2003, cyt. za: S. Nedeljković, Čast, krv i suze. Ogledi iz antropologije etniciteta i nacionalizma, Beograd, 2007, s. 273. 
gijnych model kształtowania rodzimego - narodowego oblicza prawosławia (dotyczy to między innymi różnic w ustroju wewnętrznym Cerkwi, odrębnych relacji z władzą polityczną (metropolici jako władcy świeccy, związków z Kościołem łacińskim czy zasady tolerancji stosowanej w środowisku multietnicznym).

Przypomnijmy tu, że proces autonomizacji czarnogórskiej Cerkwi, rozpoczęty jeszcze w 1993 roku, oraz nowszy - proces kształtowania wąsko narodowego oblicza prawosławia - od samego początku określał jedynie z pozoru cerkiewny, de facto w przeważającej mierze polityczny tryb myślenia. Był on nakierowany na podstawowe kwestie dotyczące genezy i autokefalii Cerkwi Czarnogórskiej (w tym potwierdzonego dokumentami co najmniej od XVI wieku prawa do „niezależnej drogi do Boga", przerwanej w 1918 roku), ale także - z perspektywy Serbskiej Cerkwi Prawosławnej (dalej SCP) - na prekursorów oraz wszelkich zwolenników idei autokefalii jako atrybutu niezależności państwowej i narodowej. Spór wokół tych kwestii prowadzony przez zwierzchników obydwu Cerkwi, wspierany całkowicie odmiennie przez serbskich i czarnogórskich historyków interpretowaną dokumentacją, obecny jest od lat dziewięćdziesiątych ubiegłego wieku także w codziennej publicystyce $i$, niestety, poddawany skrajnej polityzacji. Dyskurs ten jest powszechnie znany i został już częściowo omówiony w kilku opracowaniach naukowych ${ }^{13}$.

Z punktu widzenia dyskusji nad kanonem tradycji kulturowej Czarnogórców i roli prawosławia jako ich kodu (auto)identyfikacyjnego równie ważne jak trwający od ponad dwudziestu lat „raskoł” pomiędzy SPC (a właściwie jej reprezentantem na tym obszarze - Metropolią Czarnogórsko-Nadmorską i jej zwierzchnikiem biskupem Amfilohije) a tzw. Autokefaliczną Cerkwią Czarnogórską, postrzeganą z perspektywy Cerkwi-Matki (tj. SCP) jako „odszczepieńcza”, „heretycka” „organizacja pozarządowa”, na czele której stoi „herezjarcha” Miraš Dedeić (patriarcha Mihailo) ${ }^{14}$, są usilne próby afirmacji prawosławia w wymiarze ściśle narodowym - czarnogórskim, potwierdzające jego dziejową odrębność wobec modelu serbskiego. Wśród podejmowanych wysiłków na rzecz umocnienia elitarnej wiary „crnogoroslavlja” ${ }^{15}$ naj-

${ }^{13}$ Por. np. Ž. Andrijašević, Crnogorska crkva 1852-1918 (studija sa zbirkom dokumenata o Pravoslavnoj crkvi u Knjaževini/Kraljevini Crnoj Gori), Nikšić 2008, s. 187-205. Autorka niniejszego tekstu również w wielu miejscach prezentowała szerzej te zagadnienia-por. np. D. Gil, Religija kao kod identiteta - savremene kulturne i književne naracije o verskoj identifikaciji Crnogoraca [w:] Njegoševi Dani IV. Zbornik radova Medjunarodni Naučni skup /Kotor 31.08-3.09.2011/, ured. T. Bečanović, Nikšić 2013, s. 91-102.

${ }^{14}$ Szerzej na temat omawianego raskołu zob. D. Gil, Współczesne oblicza raskołu i herezji w perspektywie kulturowych relacji serbsko-czarnogórskich, „Studia Litteraria Universitatis Iagellonicae Cracoviensis ", nr 9/2014, s. 86-94.

${ }^{15}$ Czy też crnogoslavlja. Twórcą terminu pochodzącego z czasów II wojny światowej jest Sekula Drljević (1884-1945) - polityk, prawnik i pisarz uznawany w Czarnogórze za patriotę i głównego ideologa państwa oraz religijnej tradycji Czarnogórców; przez Serbów postrzegany jako postać niezwykle kontrowersyjna - współpracownik władz faszystowskiego państwa chorwackiego (NDH), kolaborant 
ważniejsze stały się zatem próby przeciwstawienia wielowiekowej zmanipulowanej „savizacji” czarnogórskiej przestrzeni duchowej (chodzi o - jak się podkreśla - narzucony Czarnogórcom kult św. Savy) - jej ,ppetryzacji” (choć oczywiście ukuty od imienia św. Piotra Cetińskiego (Petar Cetinjski) termin ,„petroslavlje” nie wydaje się być adekwatną przeciwwagą dla serbskiego upolitycznionego svetosavlja ${ }^{16}$ ). Strategię kodyfikacji narodowego oblicza prawosławia wyznaczają przy tym nie tylko próby przeciwstawiania toposów „ojców-założycieli” (narodu serbskiego - św. Savy i prawodawczego „ojca czarnogórskiego państwa” oraz „wybrańca Bożego” - św. Piotra Cetińskiego), ale też instrumentalizowane na potrzeby każdej ze skonfliktowanych Cerkwi kulty świętych. Za przykład może posłużyć kanonizacja władcy Zety Ivana Crnojevicia - ,fundatora autokefalicznej CCP” oraz mecenasa kultury i - odpowiednio ze strony metropolity SCP Amfilohija - kontrowersyjna (także z powodu ,nieortodoksyjności” jego myśli) kanonizacja „serbskiego” władyki Petara II Petrovicia Njegoša jako ,emblematu etnicznego” w 2013 roku, lecz również swoista „montenegryzacja" katolickich świętych (Elena di Savoia - czarnogórska księżniczka Jelena Petrović Njegoš) i Bokelijczyków (pochodzących z rejonu zatoki świętych - Boki Kotorskiej) utożsamianych jednak przede wszystkim z Włochami (Ozana/Hosana Kostić, zmarli w Wenecji: oczekująca na [prawdopodobnie rychłą] beatyfikację Ana Marović czy Blaženi Gracije, Bogdan Mandić i inni $)^{17}$.

Nie ulega przy tym wątpliwości, że wszelkie podejmowane przez zwolenników CCP wysiłki na rzecz usamodzielnienia się „odrodzonego” narodowego Kościoła oraz umocnienia ,crnogoroslavlja” wpisywane są w obręb doraźnej polityki od niedawna niezależnego państwa, wciąż zmagającego się z problemem swojej autoidentyfikacji na płaszczyźnie wewnętrznej i międzynarodowej. Równie upolitycznione, by nie powiedzieć skrajnie radykalne (jeśli wziąć pod uwagę choćby próby nakłaniania patriarchy moskiewskiego do falsyfikowania dokumentów potwierdzających autokefalię czarnogórskiej Cerkwi ${ }^{18}$, czy kierowane w ostatnich latach do prezy-

ustaszowski i niemiecki. Zob. S. Nedeljković, op.cit., s. 274; Demokratija i sabornost. Zbornik radova, ured. Z. Milošević, Beograd 2010, s. 113 oraz D. Gil, Religija kao kod..., s. 97.

${ }^{16} \mathrm{Na}$ temat zideologizowanego svetosavlja - świętosawia zob. D. Gil, Prawostawie. Historia. Naród. Miejsce kultury duchowej w serbskiej tradycji i wspótczesności, Kraków 2005, s. 38-40.

${ }^{17}$ Por. Ž. L. Djurović, B. Cimeša, N. Adžić, D. Ivezić, Crnogorski sveci, slave i običaji, Zagreb 2005, s. 76-84 oraz B. Brković, Svi crnogorski sveci, http://www.montenegrina.net/pages/pages1/religija/ svi crnogorski sveci.htm, dostęp 17.09. 2013. Na ten temat szerzej pisałam w artykule: Kulty świętych jako świadectwo tożsamości etniczno-kulturowej - współczesny panteon Montenegrinorum Sanctorum [w:] Obraz świętości - świętość w obrazie, red. I. Lis-Wielgosz, W. Jóźwiak, P. Dziadul, Poznań 2014, s. 123-131

${ }^{18}$ W liście skierowanym do patriarchy Aleksego II z 1992 roku metropolita Amfilohije wzywa go do potwierdzenia, że użyte w dyptychu RCP z 1850 roku sformułowanie dotyczące autokefalicznej CCP było niezgodne z prawdą (niekanoniczne i błędne) i by je po upływie półtora wieku skorygował. Por. S. Nedeljković, op.cit., s. 281. 
denta Putina prośby o ochronę rzekomo dyskryminowanej w Czarnogórze Cerkwi serbskiej) działania metropolity Amfilohija ów raskoł (czy też jedynie ostry konflikt cerkiewno-polityczny) znacząco pogłębiają. Wciąż pod wieloma względami wspólna serbsko-czarnogórska kulturosfera okazuje się przy tym obszarem często sztucznie antagonizowanym, w którym prawosławie - istotny element tożsamości kulturowej i narodowej obydwu narodów, ale także dynamicznie umacniający swą pozycję w tym regionie islam - stają się narzędziem w służbie doraźnej polityki. Czynnik geopolityczny ostatecznie okazał się w tej grze prymarny, podporządkowując sobie wszelkie fakty kulturowe z przeszłości oraz kształtując stosunek do zjawisk teraźniejszych na geograficznym i kulturowo-religijnym obszarze wpływu kilku hegemonów politycznych ${ }^{19}$, wyrastających z całkowicie odrębnych tradycji kulturowych.

\section{Bibliografia}

Adžić, N., Kratka istorija Crnogorske pravoslavne crkve (od sredine XV vijeka do 1920. godine), Cetinje 2000.

Andrijašević, Ž., Crnogorska crkva 1852-1918 (studija sa zbirkom dokumenata o Pravoslavnoj crkvi u Knjaževini/Kraljevini Crnoj Gori), Nikšić 2008.

Andrijašević, Ž., Rastoder Š., Istorija Crne Gore od najstarijih vremena do 2003 (prvi dio), Podgorica 2006.

Andrijašević, Ž., Srpstvo u Crnoj Gori [w:] DOCLEA. Posebno izdanje - serija L: Falsifikati crnogorske prošlosti. Zbornik radova DANU, organizacioni odbor B. Nikolić et al., Podgorica 2011, s. 91-108.

Andrijašević, Ž., Crna gora vjekovima zavisila od strane pomoći - njenu privrženost najskuplje je plaćala Rusija, http://www.montenegrina.net/pages/pages1/istorija/cg_u xix_vijeku /cg vjekovima je zavisila_od strane pomoci.htm.

Bońkowski, R., Stowianie środkowopołudniowi na przełomie XX i XXI wieku. Język-Religia - Naród-Państwo, Katowice 2010.

Brković, B., Svi crnogorski sveci, http://www.montenegrina.net/pages/pages1/religija/svi crnogorski sveci.htm.

Demokratija i sabornost. Zbornik radova, ured. Z. Milošević, Beograd 2010.

${ }^{19}$ Na szczególną uwagę zasługuje tu niewątpliwie wielowiekowe kulturowe i polityczne odziaływanie Rosji, jako głównego hegemona politycznego w regionie, jednak ze względu na ograniczenia tekstowe problem ten nie może być tutaj omówiony szerzej. Z bogatej literatury przedmiotu na ten temat zob. np. V. Dj. Petrov, Vjekovi duhovnog zajedništva Crne Gore i Rusije. Književno-istorijsko ogledalo 1494-2002, ured. B. Ostojić, CANU: Posebna izdanja knj. 46, Podgorica 2004 oraz Andrijašević Ž, Crna gora vjekovima zavisila od strane pomoći - njenu privrženost najskuplje je plaćala Rusija, http:// www.montenegrina.net/pages/pages $1 /$ istorija/cg_u_xix_vijeku/cg_vjekovima_je_zavisila_od_strane pomoci.htm, dostęp: 18.09.2014. W ostatnim dziesięcioleciu ostrą cezurę w dotychczas ścisłych i przyjaznych relacjach politycznych i ekonomicznych wyznaczył niedoszły zamach na prezydenta Milo Djukanovicia, w który zamieszani byli agenci rosyjscy i serbscy (październik 2016), nade wszystko jednak przystąpienie Czarnogóry do NATO w czerwcu 2017 roku. 
Djurović, Ž. L., Cimeša B., Adžić N., Ivezić D., Crnogorski sveci, slave i običaji, Zagreb 2005.

Džomić, V. (protojerej), , Crnogorska” lažna crkva, Novi Sad-Podgorica 2008.

Gil, D., Prawosławie. Historia. Naród. Miejsce kultury duchowej w serbskiej tradycji i wspótczesności, Kraków 2005.

Gil, D., Religija kao kod identiteta - savremene kulturne i književne naracije o verskoj identifikaciji Crnogoraca [w:] Njegoševi Dani IV. Zbornik radova Medjunarodni Naučni skup /Kotor 31.08-3.09.2011/, ured. T. Bečanović, Nikšić 2013, s. 91-102.

Gil, D., Kulty świętych jako świadectwo tożsamości etniczno-kulturowej - współczesny panteon Montenegrinorum Sanctorum [w:] Obraz świętości - świętość w obrazie, red. I. Lis-Wielgosz, W. Jóźwiak, P. Dziadul, Poznań 2014, s. 123-131.

Gil, D., Współczesne oblicza raskołu $i$ herezji w perspektywie kulturowych relacji serbsko-czarnogórskich, „Studia Litteraria Universitatis Iagellonicae Cracoviensis”, nr 9/2014, s. 86-94.

Lutovac, Z., Srpski identitet u Crnoj Gori, Beograd 2015.

Nedeljković, S., Čast, krv i suze. Ogledi iz antropologije etniciteta i nacionalizma, Beograd 2007.

Nikolaidis, A., Mimesis, Podgorica 2003.

Perazić, G., Kuda ide Crna Gora, Beograd 1999.

Petrov, V. Dj., Vjekovi duhovnog zajedništva Crne Gore i Rusije. Književno-istorijsko ogledalo 1494-2002, ured. B. Ostojić, CANU: Posebna izdanja knj. 46, Podgorica 2004.

Popović, M., Podijeljena nacija. Identitet, država, vlast, Podgorica 2010.

Stavovi crnogorskih gradjana o idetitetu. Istraživanje CEDEM-a sa komentarom, http://www. maticacrnogorska.me/files/54/04\%20crnogorski\%20gradjani\%20o\%20identitetu.pdf.

Rezultati popisa u Crnoj Gori, http://popis2011.wordpress.com/2011/07/12/zvanicni-rezultati-popisa-crnogoraca.

Sudnik, K., Regionalne modele (auto)identyfikacji a integracja kulturowa i narodowa we współczesnej literaturze czarnogórskiej - rozprawa doktorska napisana pod kier. dr hab. Doroty Gil, prof. UJ, obroniona w 2016 roku na Uniwersytecie Jagiellońskim.

Špadijer, M., Czarnogóra przed i po referendum [w:] Bunt tradycji-tradycja buntu, Księga dedykowana Profesorowi Krzysztofowi Wrocławskiemu, red. M. Bogusławska, G. Szwat-Gyłybowa, Warszawa 2008, s. 195-207.

Wrocławski, K., Mniejszość we własnym kraju? - rzecz o Czarnogórcach [w:] Literatury słowiańskie po roku 1989. Nowe zjawiska, tendencje, perspektywy, t. IV: Mniejszości, red. M. Dąbrowski, Warszawa 2005, s. 158-168.

Vukadinović, S., Uticaj djelovanja vjerskih zajednica na stanje religijske svijesti pripadnika društvenih grupa u Crnoj Gori [w:] Učenje, organizacija i delovanje verskih zajednica i pokreta (V godišnja medjunarodna konferencija JUNIR), ured. D. B. Djordjević, JUNIR V, Niš 2001, s. 82-87.

Zečević, N., Beograd je frustriran rezultatima popisa - razgovor sa predsjednicom Helsinškog komiteta Sonjom Biserko (19.07.2011), http://www.portalanalitika.me/politika/ tema/32150-beograd-je-frustriran-rezultatima-popisa html. 